\title{
Urbanization and pollution of surface water resources in the two largest cities in Ghana
}

\author{
Isaac Monney ${ }^{1}$, Robert Boakye ${ }^{2}$, Richard Buamah ${ }^{2}$, Frederick Oppong Kyekyeku Anyemedu ${ }^{2}$, \\ Samuel Nii Odai ${ }^{2}$, Esi Awuah ${ }^{3}$ \\ ${ }^{1}$ Department of Environmental Health and Sanitation Education, University of Education, Winneba, Mampong Ashanti, Ghana \\ ${ }^{2}$ Department of Civil Engineering, Kwame Nkrumah University of Science and Technology, PMB, Kumasi, Ghana \\ ${ }^{3}$ Office of the Vice Chancellor, University of Energy and Natural Resources, Sunyani, Ghana
}

\section{Email address:}

monney.isaac@gmail.com (I. Monney)

\section{To cite this article:}

Isaac Monney, Robert Boakye, Richard Buamah, Frederick Oppong Kyekyeku Anyemedu, Samuel Nii Odai, Esi Awuah. Urbanization and Pollution of Surface Water Resources in the Two Largest Cities in Ghana. International Journal of Environmental Monitoring and Analysis. Vol. 1, No. 6, 2013, pp. 279-287. doi: 10.11648/j.ijema.20130106.12

\begin{abstract}
Pollution of freshwater resources draining urban centres in the developing world poses a threat to human health and environmental sustainability. This, apart from inadequate infrastructure, is primarily propelled by explosive urban populations. The study seeks to determine the level of pollution and sources of pollution in selected surface water resources in Accra and Kumasi. Water samples from specific locations of the Aboabo river in Kumasi and the upper reaches of the Korle Lagoon in Accra were collected and analysed for their physico-chemical and microbial quality during the study period. The results from the study pointed out that the upper reaches of the Lagoon is rendered anaerobic during the dry season and with appreciably low DO even during the wet season. Drastic depreciation in DO levels in the Aboabo river as it flows through highly populated areas (Aboabo, Moshie Zongo and Anloga) were depicted through the study. Elevated BOD (upper reaches of the Korle Lagoon: 27.7 - 200mg/L; Aboabo river: 38.25mg/L - 260mg/L) and E. coli (upper reaches of the Korle Lagoon:

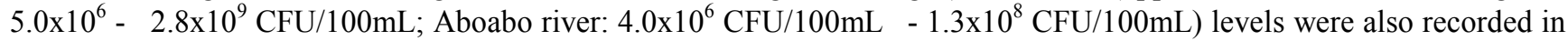
both waterbodies generally attributed to disposal of organic wastes and faecal matter into them. An integrated approach that takes cognizance of both technical and socio-economic factors behind this phenomenon is proposed by the study.
\end{abstract}

Keywords: Water Quality, Pollution, Aboabo River, Kumasi, Korle Lagoon, Accra

\section{Introduction}

Water is an essential and life-sustaining resource for humans and all life forms on Earth. As far as human existence and development is concerned, water plays a crucial role in agricultural, domestic, industrial, recreational, religious activities among others. Due to the enormous importance of water for human development, early civilisations thrived along waterbodies such as the Nile, Tigris and Euphrates in ancient Mesopotamia, Indus in India, and Huang $\mathrm{He}$ in China [1]. Studies have shown that, without access to potable water, all efforts aimed at reducing poverty and protecting public health will be futile [2,3].

Yet much attention has not been devoted to adequately protect this all-important resource. This is confirmed by the fact that about 2million tons of waste are disposed off within receiving waters daily [4]. Particularly in urban centres in the developing world, surface water resources, have become dumpyards for waste [5,6]. In Ghana's national capital, Accra, faecal matter is discharged directly into the sea at Lavender Hill without any form of treatment while significant amount of solid waste also end up in surface water bodies in most urban areas in the country [7,8]. Consequently, these practices have rendered most surface water resources unsuitable for both primary and/or secondary usage [9].

Available literature $[10,11]$ indicate that the environmental challenges in the developing world has been fuelled by the great waves of urbanisation and inadequate urban infrastructure. Globally, the African continent has the highest rate of urbanization with an annual growth rate of 3.5\% [12] while Sub-Saharan Africa tops the global urbanization chart on the measure of rate of growth of urban populations [13]. In Ghana, the annual growth rates of major cities such as Accra (4.3\%) and Kumasi (5.6\%) are almost twice as 
high as the national growth rate of $2.5 \%[14,15]$. City authorities have therefore not escaped the attendant challenges of urbanization which include among other things, the handling and disposing of the copious amounts of waste produced. Due to inadequate infrastructure between $65 \%$ and $75 \%$ of the solid waste generated is collected in Accra while in Kumasi and Tamale about $70 \%$ and $27 \%$ of solid waste is collected $[16,17,18]$. Poor access to improved sanitation has also exacerbated the problem in that, only $19 \%$ of urban residents have access to improved sanitation. Heaps of refuse, open drains and streams filled with wastewater and solid waste are therefore not uncommon sights in urban areas. These practices have dire consequences on the environment through biological and chemical pollution of groundwater and surface water resources with adverse effects on human health [19].

In order to institute effective mechanisms for the protection of the surface water resources in these areas it is crucial to assess the extent of pollution and identify the sources of these pollutants. It is against this backdrop that the study seeks to determine the physico-chemical and biochemical pollution status of two surface water resources in Accra (upper reaches of the Korle Lagoon) and Kumasi (Aboabo river) and identify the types and sources of such pollutants.

\section{Materials and Methods}

\subsection{Study Areas}

The study was conducted in Accra and Kumasi; the two largest cities in Ghana. In Accra, the upper reaches of the Korle Lagoon, forming part of the Odaw catchment was used for the study while in Kumasi, the Aboabo river was assessed.

The Korle Lagoon, located at the south-west of the central business district of Ghana's national capital, Accra, is the major drainage basin into which the greater portion of floodwaters of the Accra Metropolis flows before entering the sea $[20,21]$. It receives water from the Odaw River and two major drains on its eastern and western sections [20]. The Lagoon covers a total surface area of about 0.6 $\mathrm{km} 2$ and drains a total catchment area of about $400 \mathrm{~km} 2$ [20]. The catchment area of the Lagoon includes Dome, Legon, Achimota, Kaneshie, Abossey Okai, Ring Road Industrial Area and the high density low income areas of Nima, Maamobi and Accra Newtown. Apart from being densely populated, the catchment area has a large concentration of industries including Accra Breweries Limited, several textile factories and vehicle repair workshops. It is estimated that about $80 \%$ of all the industries in Accra are located in the lower drainage basin of Korle/Odaw complex [22].

Taking its source from Tafo-Pankorono at the Northern part of the Kumasi Metropolis, the Aboabo River flows southwards through Moshie Zongo, Buokrom, Aboabo, Anloga to connect with the Sisa river at a confluence at
Asokwa and continues to Atonsu. It has a length of $16.6 \mathrm{~km}$ from source to the downstream end - Atonsu flowing at an average velocity of $0.87 \mathrm{~m} / \mathrm{s}$. It is estimated that the Aboabo River basin is home to about a quarter of the city's over 2 million residents [1]. The basin is also a hub of several small- and large-scale industries including palm kernel oil extraction companies, charcoal producing business, metal scrap dealers, leather tanning industries, car washing bays, among others. Effluents from these businesses end up in the Aboabo river without any treatment posing adverse repercussions on human and environmental health. The locations of the study areas are shown in Figure 1.

Sub-surface water samples were taken from pre-determined sampling points at the upper reaches of the Korle Lagoon and the Aboabo River. For the upper reaches of the Korle Lagoon, samples were taken in May, June and July, 2010 and then from November to February, 2011 from four sampling points (Figure 2). Water samples were taken from seven sampling points (Figure 3) on bi-monthly basis in November, 2011 and January, 2012 for the Aboabo river.

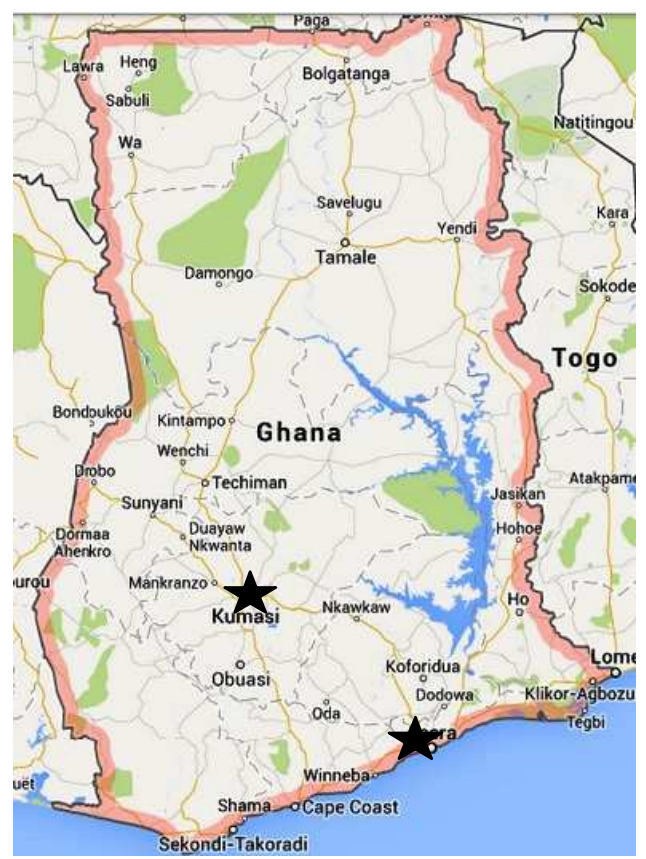

Figure 1. Map of Ghana showing Accra and Kumasi (Courtesy: Googlemaps)

The samples were collected with 1.5 litre sterilized plastic bottles and $300 \mathrm{~mL}$ BOD bottles for the analysis of microbial and some chemical parameters. Both in-situ and ex-situ analyses were carried out on the samples. Electrical Conductivity (EC), Total Dissolved Solids (TDS), $\mathrm{pH}$ of samples from both Accra and Kumasi were measured in-situ with a PC 300 Waterproof $\mathrm{pH} /$ Conductivity/TDS/Temperature meter while Dissolved Oxygen (DO) was measured with a WTW Oxi 340 oximeter. Samples were preserved in an airtight ice chest at room temperature $\left(\sim 20^{\circ} \mathrm{C}\right)$ before being transported to the laboratory. All other measurements were carried out within 24 
hours after sampling. Water quality parameters that required immediate analyses; Ortho-phosphate, Nitrogen-Ammonia, Nitrate-Nitrogen were measured with a DR/2400 Spectrophotometer using appropriate reagent pillows at the Ghana Water Company Limited Laboratory in Accra and others at the Environmental Quality Engineering Laboratory at the Civil Engineering Department, KNUST, Kumasi. However, all water samples collected from the Aboabo River were analysed exclusively at the Environmental Quality Engineering Laboratory at the Civil Engineering Department, KNUST, Kumasi. Bacteriological examinations (Escherichia coli and Total coliforms) were conducted by the Membrane filtration technique using Chromocult Coliform Agar as culturing medium. All the methodologies for field and laboratory analysis were conducted according to the Standard Methods for the Examination of Water and Wastewater [23]. Extensive field surveys were carried out to identify the sources of pollution within the catchment areas of the waterbodies. Single factor ANOVA with 5\% significance level was used to determine the statistical significance of the variation of the parameters analysed.

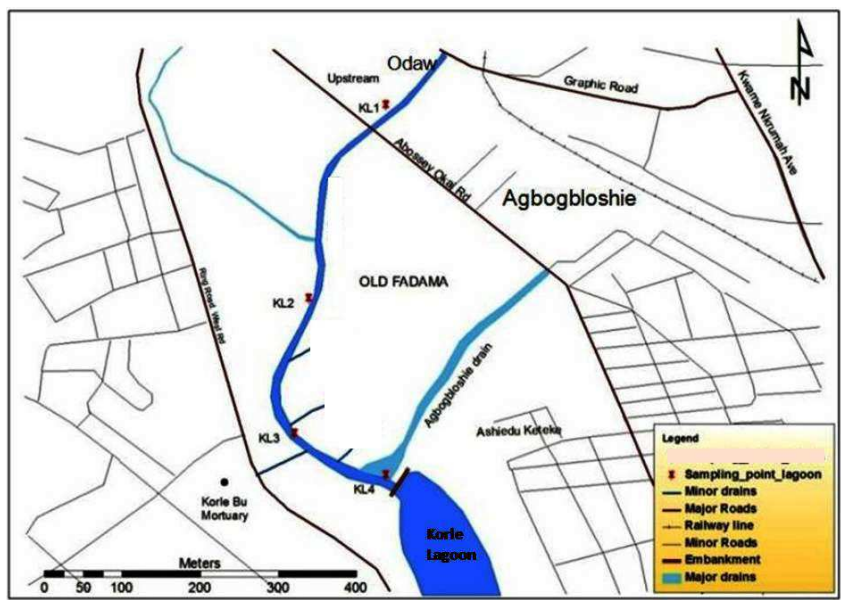

Figure 2. Location of sampling points for the upper reaches of the Korle Lagoon (Author's map)

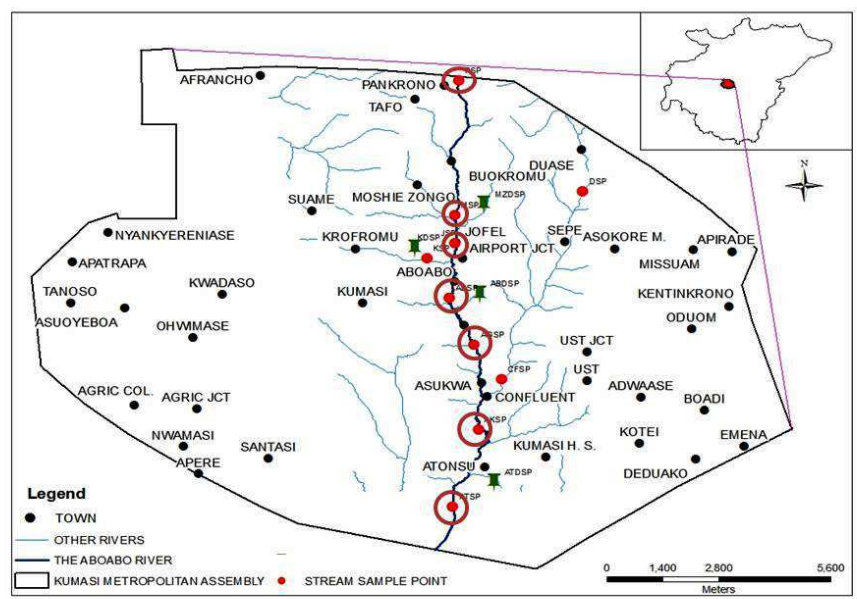

Figure 3. Location of sampling points for the Aboabo river (Author's map)

\section{Results and Discussion}

\subsection{Physico-Chemical Parameters}

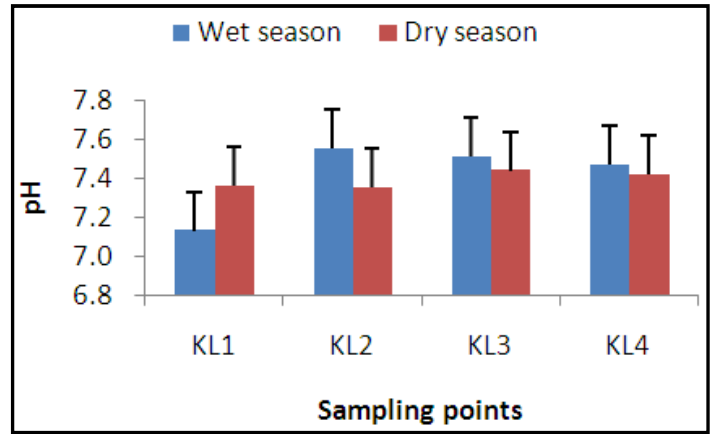

Figure 4. pH of the upper reaches of the Korle Lagoon

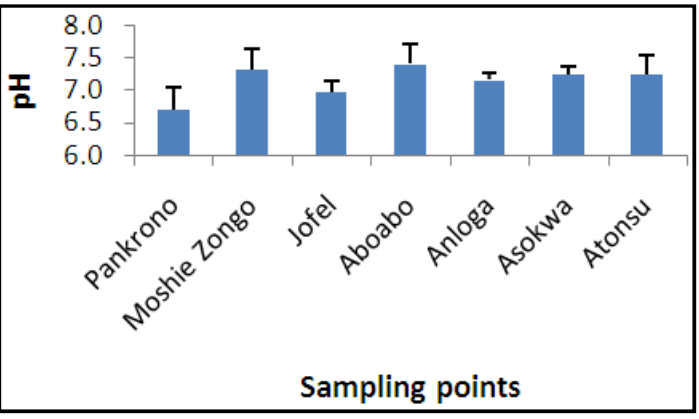

Figure 5. pH of the Aboabo river

The $\mathrm{pH}$ of the upper reaches of the Korle Lagoon was between 7.13 and 7.55 in the wet season and $7.35-7.44$ in the dry season. The $\mathrm{pH}$ was slightly alkaline (Figure 4) during the study period and confirms earlier studies by [20] who attributed this to seawater intrusion Seasonal variation of $\mathrm{pH}$ was not statistically significant. For the Aboabo river, the $\mathrm{pH}$ values were between 6.16 and 7.78 throughout the sampling period (Figure 5). Statistically, $\mathrm{pH}$ variation along the Aboabo river was significant. $\mathrm{pH}$ values were within the allowable $\mathrm{pH}$ range of 6.5-8.5 for freshwater bodies. According to [10] $\mathrm{pH}$ levels of waterbodies can have detrimental effects on aquatic lives if it is too acidic or too alkaline. Acidic waters could contain high levels of toxic metals that could affecting the aesthetic nature of the water and usability for domestic purposes.

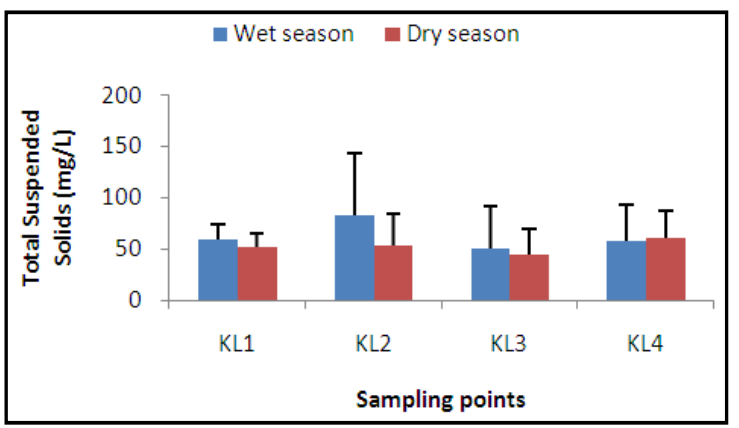

Figure 6. Total suspended solids in the upper reaches of the Korle Lagoon 


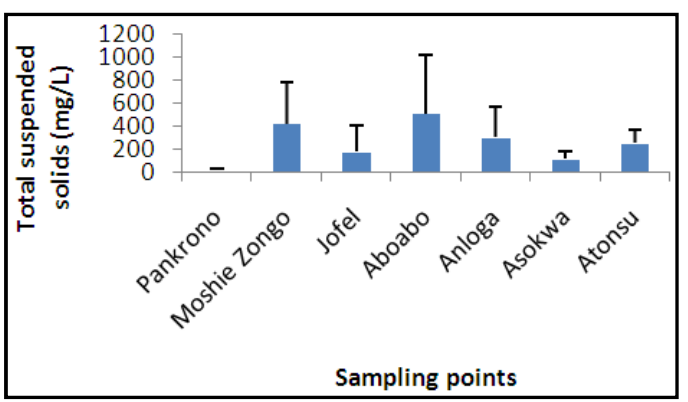

Figure 7. Total suspended solids in the Aboabo river

Levels of total suspended solids in the upper reaches of the Korle Lagoon were relatively higher in the wet season as compared to the dry season varying between 50.21 $83.41 \mathrm{mg} / \mathrm{L}$ (wet season) and $44.34-61.0 \mathrm{mg} / \mathrm{L}$ (dry season) on the average. A drastic increase in TSS in the wet season $(83.41 \pm 59.74 \mathrm{mg} / \mathrm{L})$ is observed at KL2 (sampling point along an urban slum community - Figure 6) indicating an influx of particle-laden inflow from the community into the waterbody. These values are however lower than those reported by [20] for the outlet of the Korle lagoon; 195-260 $\mathrm{mg} / \mathrm{L}$ (spring tide) and $80-240 \mathrm{mg} / \mathrm{L}$ (neap tide) possibly indicating that the TSS of the waterbody increases as it gets into the sea. The difference between TSS levels during the wet and dry seasons could be attributed to runoff carrying various debris (solid waste and soil particles) into the waterbody during the wet season, discharge of domestic and industrial wastewater thereby increasing the TSS level. However, seasonal variation of TSS was not statistically significant.

For the Aboabo river, the TSS evidently depicts an increasing trend from the upstream (Pankrono) to the downstream (Atonsu) showcasing the impact of various human activities on the water body (Figure 7). TSS values along the Aboabo river were not statistically significant and ranged between $10-1165 \mathrm{mg} / \mathrm{L}$ with Aboabo and Moshie Zongo consistently recording higher TSS values. These areas are slum communities along the river where sewage and solid waste are indiscriminately disposed into the environment eventually ending up the water course. According to [24], higher concentrations of suspended solids can act as carriers of toxics, which are readily adsorbed by suspended particles and also increase the turbidity of water. Increased turbidity reduces light penetration needed for photosynthesis by some aquatic life [20].

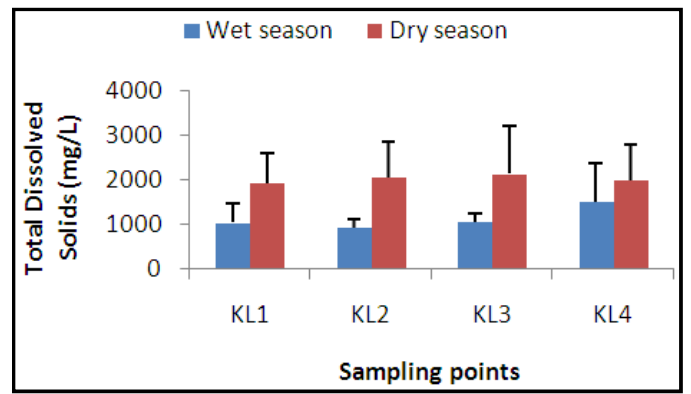

Figure 8. Total dissolved solids of the upper reaches of the Korle Lagoon

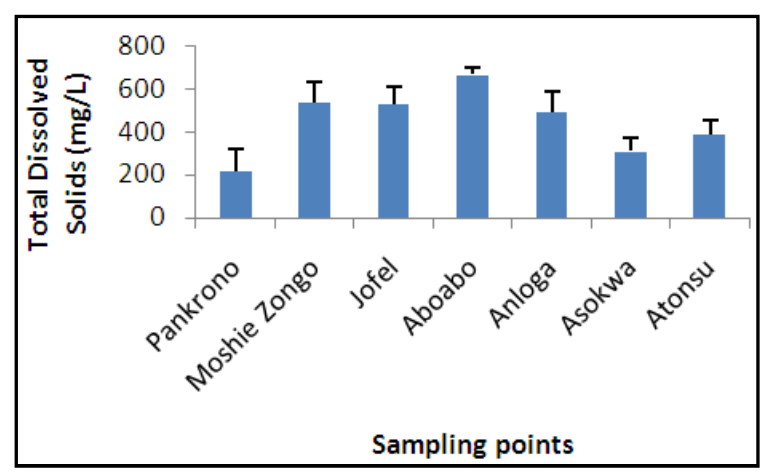

Figure 9. Total dissolved solids of the Aboabo river

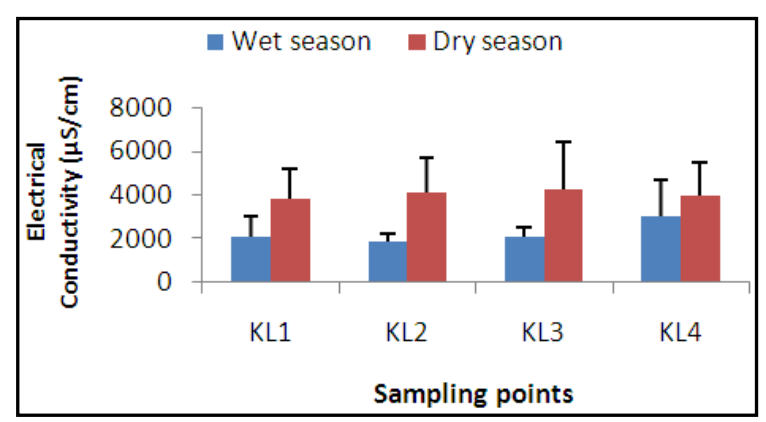

Figure 10. Electrical Conductivity of the upper reaches of the Korle Lagoon

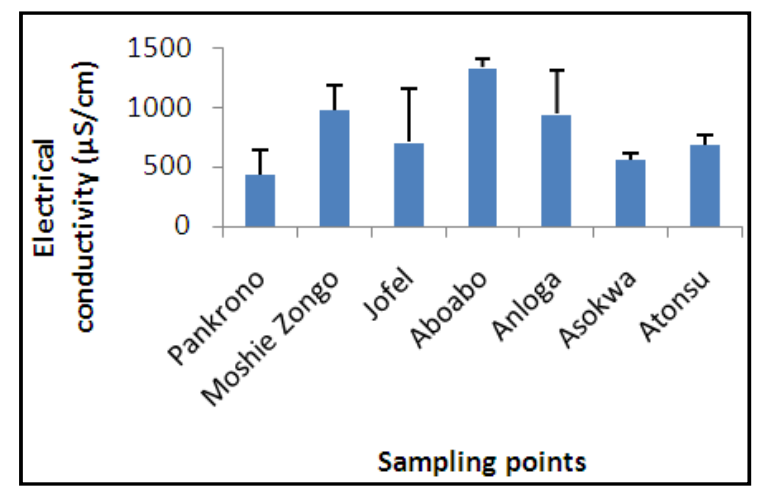

Figure 11. Electrical Conductivity of the Aboabo river

Relatively Relatively higher TDS levels were recorded in the upper reaches of the Korle Lagoon (Figure 8) as compared to the Aboabo river (Figure 9). The same trend is depicted in the levels of electrical conductivity in both streams (Figures 10 and 11). According to available literature $[23,24]$ electrical conductivity is caused by the presence of ions; conductivity increases with increasing concentration of ions. This explains the direct proportion between the levels of TDS and electrical conductivity. Average TDS levels for the upper reaches of the lagoon were also higher in the dry season $(1930-2140 \mathrm{mg} / \mathrm{L})$ as compared to the wet season $(924.1-1518.6 \mathrm{mg} / \mathrm{L})$. This is attributed to the dilution effect of rainfall runoff on the waterbody during the wet season. The variation of TDS along the upper reaches of the lagoon and seasonally were not statistically significant. TDS of the Aboabo river ranged between $96.5-700 \mathrm{mg} / \mathrm{L}$ and showed a statistically significant variation along the watercourse. 
Electrical conductivity at the upper reaches of the lagoon were higher in the dry season as compared to the wet season due to higher levels of dissolved solids in the dry season. The variations of EC along the watercourse and seasonally were not statistically significant. However, the variation of EC along the Aboabo river (192.6 - 1406 $\mu \mathrm{S} / \mathrm{cm})$ was statistically significant and appreciably lower than that of the upper reaches of the Korle Lagoon. In aquatic studies, low values of EC are characteristic of high-quality, low-nutrient waters whiles high values are indicative of salinity problems and eutrophication. Since EC is affected by the presence of inorganic solids such as chloride, nitrate, and phosphate anions, or sodium, calcium, and aluminium cations [24], higher levels of these solids in water leads to nutrient enrichment thereby affecting aquatic life. Therefore, for the sustenance of aquatic life, [25] recommends a threshold value of $1000 \mathrm{mg} / \mathrm{L}$ of TDS in surface water bodies. However, levels of TDS in the Lagoon were predominantly above this threshold, especially in the dry season (Figure 8) whiles that of the Aboabo river were consistently below this threshold (Figure 9).

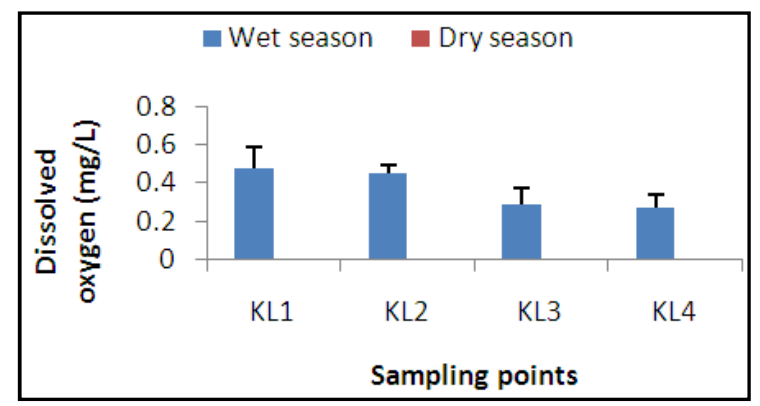

Figure 12. Dissolved oxygen in the upper reaches of the Korle Lagoon

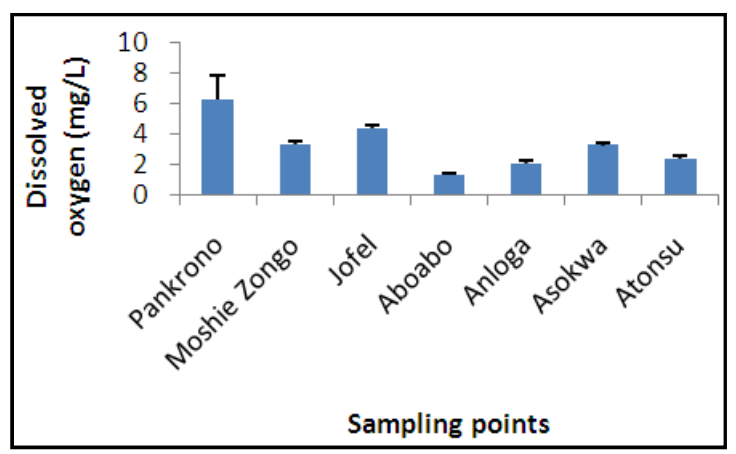

Figure 13. Dissolved oxygen in the Aboabo river

Relatively low dissolved oxygen levels were generally recorded in the upper reaches of the Korle Lagoon (Figure 12) particularly in the dry season as compared to the Aboabo river (Figure 13). DO levels were below detectable limit (approximately $0 \mathrm{mg} / \mathrm{L}$ ) in the dry season indicating the anaerobic nature of the waterbody during this season. In the wet season, though certain levels of dissolved oxygen were recorded $(0.27-0.48 \mathrm{mg} / \mathrm{L})$, this was generally below the optimum DO $(2.3 \mathrm{mg} / \mathrm{L})$ for the sustenance of aquatic life [26]. The presence of DO in the waterbody during this season could be attributed to inflow of oxygen-laden rain- fall-runoff into the waterbody and the resulting turbulence it produces within the waterbody. Moreover, since the consumption of DO is dependent on the biochemical activities taking place in the waterbody, an increase in DO could indicate a net reduction of these activities due to dilution by rainfall runoff. Although levels of DO in the upper reaches of the Lagoon showed a decreasing trend during the wet season as depicted in Figure 12, the variation was not statistically significant.

The DO levels corresponding to each sampling point in the Aboabo river indicates the relative impact of the settlements on the waterbody. As seen in Figure 13, consistently lower DO levels were recorded for the slum communities, namely Moshie Zongo $(3.33 \pm 0.19 \mathrm{mg} / \mathrm{L})$, Aboabo $(1.31 \pm 0.15 \mathrm{mg} / \mathrm{L})$ and Anloga $(2.05 \pm 0.18 \mathrm{mg} / \mathrm{L})$ located along the watercourse. These communities are characterized by indiscriminate dumping of solid waste and domestic wastewater that eventually end up in the watercourse thereby depleting the dissolved oxygen. The variation of DO along the watercourse was statistically significant.

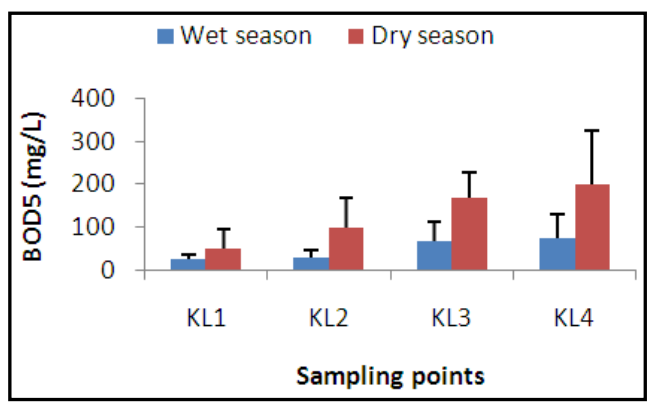

Figure 14. Biochemical oxygen demand of the upper reaches of the Korle Lagoon

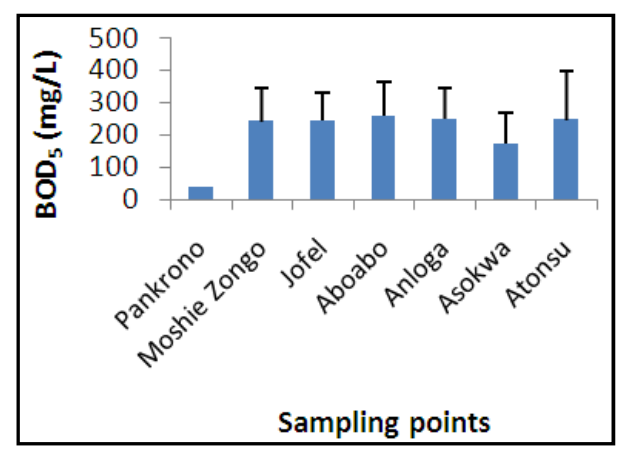

Figure 15. Biochemical oxygen demand of the Aboabo river

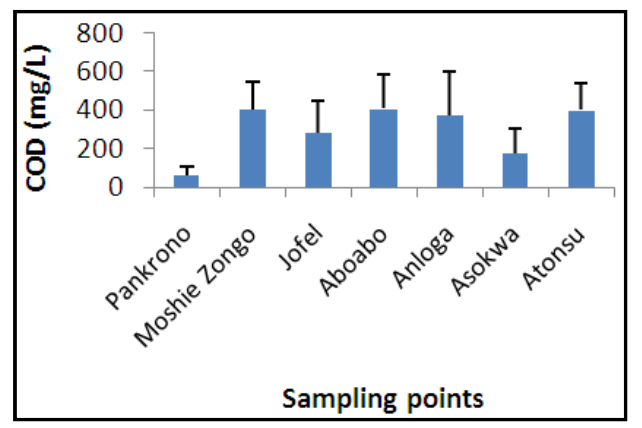

Figure 16. Chemical oxygen demand of the upper reaches of the Korle Lagoon 


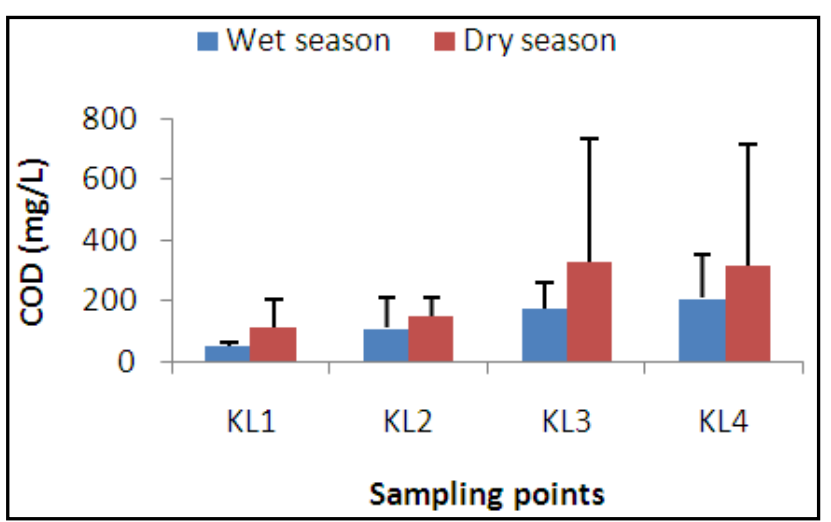

Figure 17. Chemical oxygen demand of the Aboabo river

BOD and COD are crucial in determining the extent of pollution of surface waterbodies. High BOD and COD levels indicate high oxygen demand resulting in reduced dissolved oxygen levels for aquatic life [27]. According to [20] waters with BOD less than $3 \mathrm{mg} / \mathrm{L}$ are known to have received no significant pollution discharges whiles those with BOD values more than $8 \mathrm{mg} / \mathrm{L}$ are indicative of moderate pollution. Additionally, those with BOD values of $12 \mathrm{mg} / \mathrm{L}$ or more are considered grossly polluted. In the upper reaches of the Korle Lagoon, both BOD and COD values showed increasing patterns during both seasons from the upstream section (KL1) to the downstream (KL4) - Figure 16 and Figure 17. Average BOD values for the wet season ranged from $27.7-74.8 \mathrm{mg} / \mathrm{L}$ and $50.1-200 \mathrm{mg} / \mathrm{L}$ for the dry season, indicating gross pollution as per the classification by [20]. Apart from the disposal of solid waste and wastewater into the waterbody, the high levels of BOD is also attributed to squatters who use sawdust to stabilize the banks of the waterbody in order to enable them construct their wooden houses. Although BOD and COD values in the dry season were higher than those recorded in the wet season, their seasonal variations was not statistically significant. Relatively higher BOD and COD values were also recorded for the sections of the Aboabo river within the slum communities along its course; Aboabo, Moshie Zongo and Anloga. BOD values showed a statistically significant variation from the upstream section to the downstream, ranging from $38.25 \mathrm{mg} / \mathrm{L}-260 \mathrm{mg} / \mathrm{L}$ and increased by approximately 7 times within the slum communities (Figure 16). These high levels of BOD in the waterbodies are as a result of poor waste management practices in communities in the catchment area, especially at Aboabo, Moshie Zongo and Anloga where both solid and liquid waste are eventually disposed into the Aboabo river. These practices have the tendency to disrupt aquatic life through the creation of anaerobic conditions. COD values showed a similar trend as BOD (Figures 16 and 17) but its variation along the $\mathrm{Ab}$ oabo river was not statistically significant.

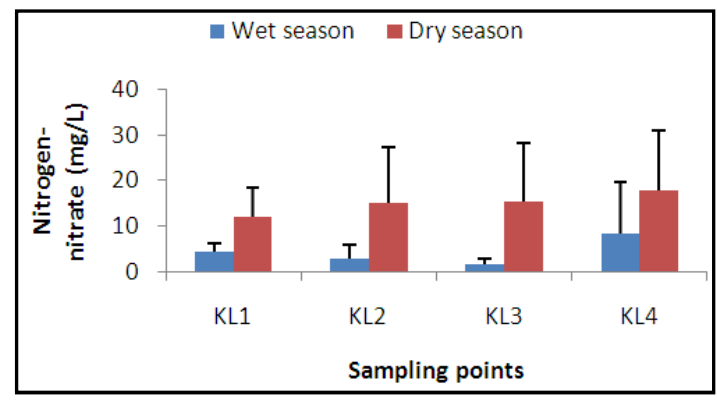

Figure 18. Nitrogen-nitrate in the upper reaches of the Korle Lagoon

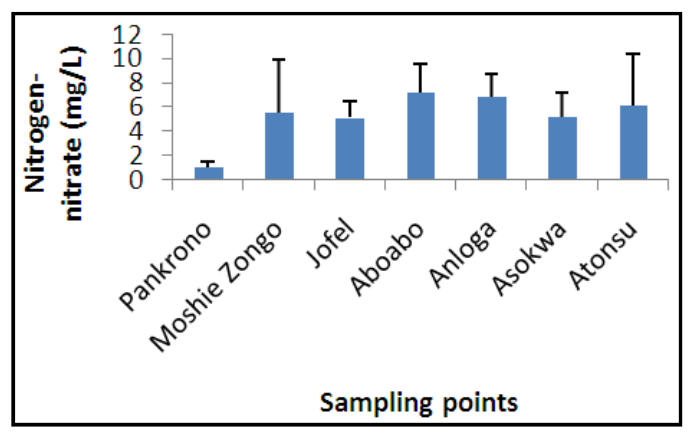

Figure 19. Nitrogen-nitrate in the Aboabo river

Nitrate, according to [28] is produced from nitrite which also results from the aerobic decomposition of organic nitrogen and ammonia. Thus, the presence of nitrates indicates that aerobic decomposition has taken place already and that the organics have had time to oxidise completely thereby producing nitrates [27]. Levels of nitrate in the upper reaches of the Korle Lagoon were higher in the dry season $(12.1-18.0 \mathrm{mg} / \mathrm{L})$ as compared to the wet season $(1.8$ $8.4 \mathrm{mg} / \mathrm{L}$ ) signifying a higher extent of decomposition of proteinaceous matter during the dry seasons as compared to the wet season (Figure 18). Nitrate concentrations in the Aboabo river also ranged from $1.0-7.2 \mathrm{mg} / \mathrm{L}$. Relatively higher nitrate levels were recorded in the slum communities (Figure 19) but in general did not show a statistically significant variation along its course. Generally the sources of nitrates include animal feedlots, municipal wastewater and sludge, fertilizers, manure, septic systems and nitrogen fixation from the atmosphere by legumes and bacteria $[29,10]$.

\subsection{Microbial Parameters}

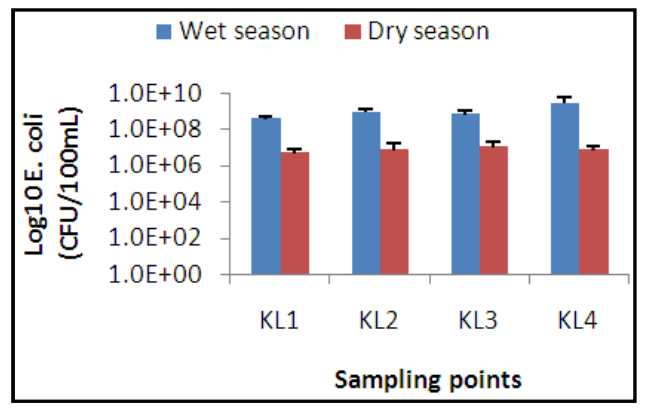

Figure 20. E. coli in the upper reaches of the Korle Lagoon 


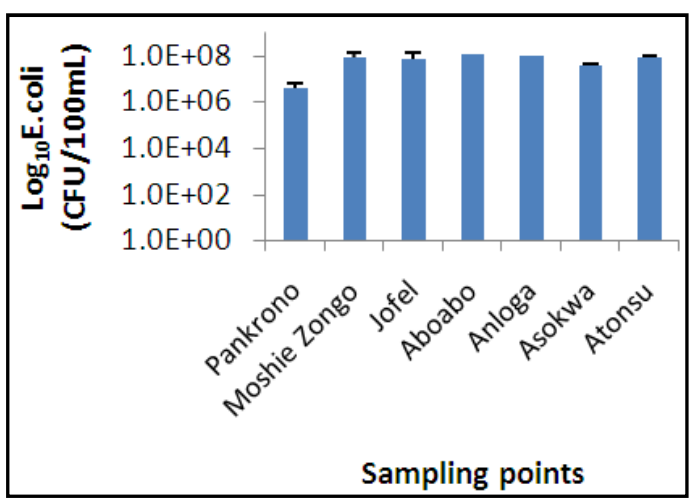

Figure 21. E. coli in the Aboabo river

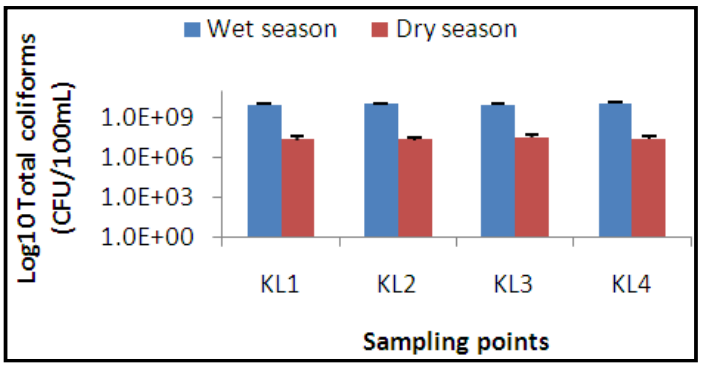

Figure 22. Total coliforms in the upper reaches of the Korle Lagoon

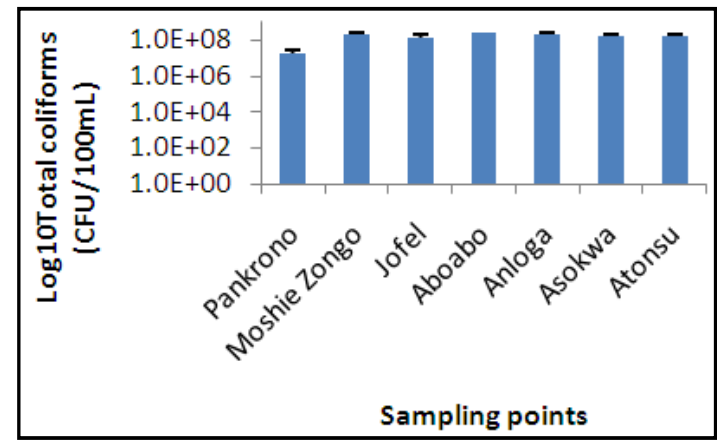

Figure 23. Total coliforms in the Aboabo river

Coliform levels ( $E$. coli and total coliforms) in both waterbodies were extremely high particularly at sampling points within the slum communities. For the upper reaches of the Korle Lagoon, the concentrations of E. coli were higher in the wet season as compared to the dry season (Figure 20) and varied between $4 \times 10^{8} \mathrm{CFU} / 100 \mathrm{~mL}$ and $2.8 \times 10^{9} \mathrm{CFU} / 100 \mathrm{~mL}$ for the wet season and $5.0 \times 10^{6}$ $\mathrm{CFU} / 100 \mathrm{~mL}$ and $1.1 \times 10^{7} \mathrm{CFU} / 100 \mathrm{~mL}$ for the dry season. The high levels of faecal coliforms in the waterbody is attributed to indiscriminate defecation along the waterbody even in broad daylight as observed during water sampling.

On the other hand, the concentrations of $E$. coli for the Aboabo river ranged between $4.0 \times 10^{6} \mathrm{CFU} / 100 \mathrm{~mL}$ and $1.3 \times 10^{8} \mathrm{CFU} / 100 \mathrm{~mL}$ with a statistically significant variation along the watercourse (Figure 18). This is greater than average values recorded in 1999: $1.3 \times 10^{6} \mathrm{CFU} / 100 \mathrm{~mL}$ and 2010: $3.5 \times 10^{6} \mathrm{CFU} / 100 \mathrm{~mL}$ as cited by [1]. Total coliforms also showed a similar pattern to E. coli as shown in Figures 22 and 23.

The high levels of faecal coliforms present in both wa- terbodies indicate the degree of pollution with disease-causing organisms and a reflection of the activities within their catchment areas. This poses grave health risks to both humans and aquatic life since the levels are well within the infectious dose of $10^{6}-10^{10}$ as stated by [30]. Adverse health impacts on human life include transmission of diseases through human contact with the water (boaters and swimmers) [20].

\subsection{Stemming Surface Water Pollution}

Findings from extensive field observations pointed out that the key factors that contribute to this problem include technical, economic and social issues. Technically, the dearth of waste management infrastructure in areas with high population densities, i.e. slum areas exacerbate the problem. Along the upper reaches of the Korle Lagoon lies Ghana's largest urban slum community; Old Fadama where solid waste collection containers are not available. Residents therefore resort to dumping of waste along the waterbody. Similar situations were observed in urban poor areas in Kumasi where refuse containers are left to overflow before they are collected for disposal. Toilet facilities, commonly public toilets are also inadequate and poorly managed making residents resort to open defecation. Socially, residents are also indifferent to environmental cleanliness thereby looking on unconcerned to heaps of refuse in their community. Indiscriminate littering of the environment has become customary within communities along the waterbodies. Thus, efforts to stem the spate of water pollution should incorporate behavioural change communication strategies. Moreover, there is possibly a weak enforcement of bye-laws regarding environmental cleanliness in such communities making residents unperturbed about the sanity of their immediate environment. Generally, it is observed that attempts to solve the environmental challenges are disjoint and short-sighted. Dredging of the upper reaches of the Korle Lagoon has been carried out but this has failed to achieve the necessary result due to the incessant disposal of refuse into it while illegal structures continue to spring up along these waterbodies. Therefore, a more holistic approach that takes cognizance of both the technical and social aspects would be needed to stem the spate of surface water pollution in urban centres.

\section{Conclusions}

The impact of human activities on the Aboabo river and the upper reaches of the Korle Lagoon is apparent. Blatant disregard for the environment depicted through the indiscriminate disposal of solid waste, industrial and domestic waste water coupled with open defecation within their catchment area have resulted in devastating effects on the two waterbodies. While the upper reaches of the Korle Lagoon is currently in an anaerobic state due to extremely low DO particularly in the dry season, the DO levels of the Aboabo river sags to significantly lower levels as it passes through slum areas along its course. BOD increases by approx- 
imately 7 times as the water flow through the slum communities; Aboabo, Moshie Zongo and Anloga. The waterbodies are almost saturated with faecal coliforms as confirmed by the high levels of faecal coliforms in the waterbodies - upper reaches of the Korle Lagoon: $4 \times 10^{8}$ $2.8 \times 10^{9} \mathrm{CFU} / 100 \mathrm{~mL}$ (wet season) and $5.0 \times 10^{6}-1.1 \times 10^{7}$

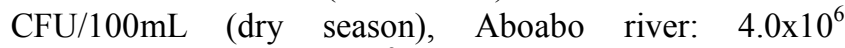
$\mathrm{CFU} / 100 \mathrm{~mL}$ and $1.3 \times 10^{8} \mathrm{CFU} / 100 \mathrm{~mL}$. Based on these findings, the study recommends frequent collection of solid waste coupled with intensive public awareness creation on environmental cleanliness through advocacy groups and local leaders. The provision of adequate sanitary facilities in these communities (especially slum communities) could reduce the spate of open defecation in these areas. Moreover, industries found culpable of disposing untreated wastewater into these waterbodies should be legally dealt with and made to pay huge fines where necessary to serve as a deterrent. In sum, strategies to restore the waterbodies should be sustainable instead of knee-jerk reactions such as only dredging although necessitated due to accumulation of sediments. There should be mechanisms in place to minimize the rampant pollution of surface water resources. To do this, a multipronged approached, consisting of ut not limited to technical and social interventions should be adopted. That is, apart from taking into consideration infrastructural requirements to stem the current situation, local action at the community level for positive behavioural change ought to be stimulated.

\section{Acknowledgement}

The authors of the study are grateful to the Netherlands Ministry of Development Cooperation (DGIS) through the UNESCO-IHE Partnership Research Fund for providing the financial support for this study.

\section{References}

[1] L. Danquah, K. Abass, and A. A Nikoi, "Anthropogenic Pollution of Inland Waters: the Case of the Aboabo River in Kumasi, Ghana", Journal of Sustainable Development. Vol. 4, No. 6, 2011, pp 103 - 115.

[2] UNDP, "Water Governance for Poverty Reduction", New York, USA, 2004, pp 2.

[3] Poverty-Environment Partnership. 2007. Linking Poverty Reduction and Water Management.URL: http://www.who.int/water_sanitation_health/resources/pover tyreduc2.pdf

[4] UNESCO-WWAP, "Water for People, Water for Life", The United Nations World Water Development Programme, Paris, France, 2003, pp 10.

[5] A. Markandya, "Water Quality Issues in Developing Countries", World Bank and University of Bath, 2004.URL: http://policydialogue.org/files/publications/Water_Quality_ markandia.pdf

[6] S. Abbaspour, "Water Quality in Developing Countries,
South Asia, South Africa, Water Quality Management and Activities that Cause Water Pollution", 2011 International Conference on Environmental and Agriculture Engineering, 2011, Vol. 15, pp 94 - 102.

[7] K. O. Boadi and M. Kuitunen, "Urban Waste Pollution in Korle Lagoon, Accra, Ghana". The Environmentalist. Vol. 22, 2002, pp 301-309.

[8] E. Awuah, and E. Fiakuma, "State of Sanitation in Accra". SWITCH: Accra Visioning and Scenario Planning Workshop, 2007, pp 1-5.

[9] S.O. Fakayode, "Impact assessment of industrial effluent on water quality of the receiving Alaro river in Ibadan, Nigeria". African Journal of Environmental Assessment and Management. Vol. 10, 2005, pp 1-13.

[10] N.K. Asare-Donkor, D.D. Wemegah, and A.A. Adimado." Chemical Analysis of Freshwater Bodies in the Kumasi Metropolis and Its Environs, Ghana". Journal of Environment and Earth Science. Vol. 3 No. 9, 2013, pp 37 - 45.

[11] T.P.Z. Mpofu, "Environmental challenges of urbanization: A case study for open green space management". Research Journal of Agricultural and Environmental Management. Vol. 2 No. 4, 2013,105-110.

[12] K. Afeku, "Urbanization and Flooding in Accra". MA Thesis (Unpublished). Miami University. Ohio, United States (2005).

[13] F. A. Armah, "Local Participation in Water Resource Management: Case Study of Old Fadama Community, Ghana". Lund University International Masters Programme in Environmental Studies and Sustainability Science (LUMES). Lund, Sweden, 2008.

[14] Ghana Statistical Service, 2010. URL: http://www.statsghana.gov.gh/greater_accra.html.

[15] UN-HABITAT . "Housing as a Strategy for Poverty Reduction in Ghana". United Nations Human Settlements Programme. UNON, Publishing Services Section, Nairobi. Kenya, 2010.

[16] K.O. Boadi, M. Kuitunen, K. Raheem and K. Hanninen, "Urbanization without Development: Environmental and Health Implications in African Cities". Environment, Development and Sustainability, Vol 7, 2005, pp 465-500.

[17] F. Puopiel, "Solid Waste Management in Ghana: The Case of Tamale Metropolitan Area", MSc Thesis, Kwame Nkrumah University of Science and Technology, Kumasi, Ghana, 2010 .

[18] S. Mariwah, "Institutional Arrangements for Managing Solid Waste in the Shama-Ahanta-East Metropolis, Ghana". Journal of Sustainable Development in Africa. Vol. 14, No. 6, 2012, pp 292-312.

[19] R. Hirata, F. Stephen, D. Gomes, M. D'Elia, and P. Marta, "Groundwater Quality Protection": A Guideline for Water Utilities, Municipal Authorities and Environment Agencies. Words and Publications. Oxford, United Kingdom, 2002.

[20] A. Y. Karikari, K. A. Asante and C. A. Biney, "Water Quality Characteristics at the Estuary of Korle Lagoon in Ghana". CSIR-Water Research Institute, Accra. Ghana, 1997.

[21] S. K. Anku, "Managing Wetlands in Accra, Ghana", African 
Regional Workshop on Cities, Ecosystems and Biodiversity, Nairobi, Kenya, 2006, pp 8.

[22] A. T. Amuzu, "The Impact of Urbanization and Development on Surface Waters in Ghana". Freshwater Contamination. Proceedings of Rabat Symposium S4, April-May 1997. IAHS Publications, 1997, No. 243. pp 117.

[23] APHA/AWWA/WEF. Standard Methods for the Examination of Water and Wastewater. 20th Edition. Washington DC, USA (1999).

[24] R. F. Spellman, Handbook of Water and Wastewater Treatment Plant Operations. Lewis Publishers, CRC Press Company. Florida, USA (2003), pp 547 - 551

[25] J.C. Akan, F.I. Abdulrahman, J.T. Ayodele and V.O. Ogugbuaja, "Impact of Tannery and Textile Effluent on the Chemical Characteristics of Challawa River", Kano State, Nigeria. Australian Journal of Basic and Applied Sciences, Vol. 3, No. 3, 2009, pp 1933-1947.
[26] USEPA. "Aquatic Life Criteria for Dissolved Oxygen (Saltwater)" Cape Cod to Cape Hatteras. Fact Sheet 2000. URL:

http://water.epa.gov/scitech/swguidance/waterquality/standa $\mathrm{rds} /$ criteria/aqlife/dissolved/dofacts.cfm

[27] R. F. Weiner, R. Matthews, J. J. Peirce and P. A. Vesilind, Environmental Engineering. 4th Edition. Butterworth Heinemann Publications. New York, USA 2003, pp 153.

[28] D. Liu, Environmental Engineers' Handbook. CRC Press. Florida, USA, 1999, pp 539 - 546.

[29] B. Shaw , C. Mechenich and L. Klessig, "Understanding Lake Data. College of Natural Resources", University of Wisconsin. Cooperative Extension Publishing Operations. Madison, USA, 2004.

[30] E. Awuah, "Pathogen Removal Mechanisms in Macrophyte and Algal Waste Stabilization Ponds". Doctoral Dissertation, UNESCO-IHE Institute for Water Education. Taylor and Francis Group/Balkema. Rotterdam, The Netherlands, 2006. 